\title{
Transplanting Legal Context without the Law: Double Criminality in Meng Wanzhou's Extradition Case
}

Sean D. Yates"

English Barrister, General Counsel of China State Construction Engineering Corporation (Middle East) L.L.C. and undertaking PhD research on new international commercial courts and their domestic relations

DOI: $10.36348 /$ sijlcj.2020.v03i09.007

| Received: 12.09.2020 | Accepted: 23.09.2020 | Published: 28.09.2020

*Corresponding author: Sean D. Yates

Abstract

Law is often transplanted from one place to another. Law is inextricably linked to its social context. In the new location, it will operate differently because the legal context changes. The law undergoes a transformation. In its new context, it might fulfill its intended purpose or satisfy a different one. In the extradition case of Meng Wanzhou, CFO of the Chinese private company, Huawei, the Canadian Court applied the double criminality test. This involved transferring the social context of the requesting jurisdiction, as it attached to the alleged conduct constituting the offence, to judge whether the domestic offence requirements could be satisfied. The social context may include background law comprising the sociolegal landscape. However, the law creating the offence is not transplanted for this purpose, as only the local law is relevant, not that of the foreign jurisdiction. This article reviews the application of the test and questions whether the deciding Court went too far by using foreign law, that creating US Sanctions against Iran, which does not exist in Canada, to satisfy a required element of the local offence. The article posits that the legal element of the transplanted 'context' shifted from passive background context to playing a performative role in the Court's decision that the double criminality test had been satisfied. It is suggested that further study of the previous work of legal comparatists might help identify the role of transplanting law and context in this aspect of the extradition process.

Keywords: Law, social context, jurisdiction, Court's decision.

Copyright @ 2020: This is an open-access article distributed under the terms of the Creative Commons Attribution license which permits unrestricted use, distribution, and reproduction in any medium for non-commercial use (NonCommercial, or CC-BY-NC) provided the original author and source are credited.

\section{INTRODUCTION}

Comparative lawyers have for over a century examined the ways different legal orders organise their laws. They have observed how law travels, how rather than reinvent the wheel, lawmakers will often copy or borrow legal ideas from another place (or time) and use it themselves [1]. Law, however, doesn't always fit. That is, it doesn't always do what it is supposed to do. It may fail to achieve its intended purpose, may do better than expected, or may end up fulfilling an unintended purpose. Comparatists have also therefore highlighted the importance of the social context from which law is taken and into which it is placed, and how the transplanting exercise inevitably results in the law in question undergoing a transformation. It is no longer

${ }^{1}$ Watson, A. (1993). Legal Transplants: An Approach to Comparative Law, University of Georgia Press; KahnFreund, O. (1974). "On uses and misuses of comparative law.” Mod. L. Rev. 37: 1. the same law because it operates differently in a different social context [2].

The double criminality ruling in the ongoing extradition proceedings involving Meng Wanzhou, CFO of the Chinese private company, Huawei, provides an interesting perspective of the legal borrowing exercise [3]. In Meng's case, in determining whether

\footnotetext{
2 Legrand, P. (1997). "The impossibility of 'legal transplants'." Maastricht Journal of European and comparative law 4(2): 111-124; Teubner, G. (1998). "Legal irritants: good faith in British law or how unifying law ends up in new divergencies." The Modern Law Review 61(1): 11-32; Miller, J. M. (2003). "A typology of Legal transplants: using sociology, Legal History and Argentine examples to explain the transplant process." The American Journal of Comparative Law 51(4): 839-886.

${ }^{3}$ United States v Meng, 2020 BCSC 785. Available at [https://www.canlii.org/en/bc/bcsc/doc/2020/2020bcsc7 85/2020bcsc785.html]
} 
the double criminality test is met, the task of examining the effect of law in a new context is reversed, as the court instead transplants the environment, or social context, to interpret whether the local law is satisfied. Critically, the foreign law itself is not transplanted, only the environment, or contextual setting, from which it must therefore be distinguished [4].

Against the accepted premise that bringing law to a new environment changes that law, when the new environment is brought to the law, can that law remain unchanged? In Meng's case, I suggest the Court sought to address issues long familiar to legal comparatists, particularly how displaced law operates and its inextricability from its social context. In so doing it has exposed the need for further attention to be given to how the double criminality test should be applied, whether different crimes attract nuanced approaches or a modified test, and how international obligations to extradite must be balanced with the individual's right to the reciprocity safeguards forming the basis of the test. Without clarification of these issues, there is increased risk of an inconsistent approach and therefore uncertainty of outcome.

The first section of this paper briefly outlines the central ideas in the literature surrounding legal transplants, now more commonly referred to as the process of legal diffusion [5] or the recognition of legal plurality [6]. These ideas can help us to understand some of the sociolegal interplay relevant to the Court's application of the double criminality test in Meng's case and so are presented before considering the substantive application. The second section looks at the facts of Meng's case and what was required of the Court, according to the law and precedent upon which it relied. The third section examines key issues the Court addressed, whether it should have imported the social context and what happened when it did. I conclude by suggesting where further research may identify

${ }^{4}$ Re Collins (No. 3) (1905), 10 C.C.C. 80 (B.C.S.C.), "you are to conceive the accused pursuing the conduct in question in this country, then along with him you are to transplant his environment; that environment must, I apprehend, include, so far as relevant, the local institutions of the demanding country, the laws affecting the legal powers and rights, and fixing the legal character of the acts of the persons concerned, always excepting, of course, the law supplying the definition of the crime which is charged."

${ }^{5}$ Twining, W. I. (2004). "Diffusion of law: a global perspective." The Journal of legal pluralism and unofficial law 36(49): 1-45.

6 Twining, W. I. (2009). "Normative and legal pluralism: a global perspective." Duke J. Comp. \& Int'1 L. 20: 473; Berman, P. S. (2012). Global Legal Pluralism: A Jurisprudence of Law Beyond Borders, Cambridge University Press. important areas of consideration that are underdeveloped.

\section{1) Legal Transplants}

a) Law and its Context

Before setting out details of the application in Meng's case, and the Court's application of the double criminality test, it is useful to be reminded of several acknowledged concepts associated with law's movement from one place to another. In the context of legal borrowing, sometimes called legal transplantation, where a body of law or legal ideas found in one legal order are used as inspiration for or largely reproduced in another legal order, the law's shifting nature has been observed and well-tracked [7]. Legal traditions from one country have been adopted by other countries, settled legal scholarship accepting that they always undergo change due to the differing social contexts between the originating and destination points. Further research categorises some of the types of change that are commonly seen. For example, where a legal transplant operates better in its new context than in its original setting, it has been referred to as 'over-fitting' [8] where its introduction is made with the deliberate intention of having a detrimental effect on some or all of those who would be subject to it, the phrase 'malicious legal transplants' has been coined [9].

Legrand argues that law cannot travel at all, because once it is taken out of context and placed into another context; it is no longer the same law and cannot operate in the same way. For him, legal transplants are impossible [10]. Others consider that legal transplants can and do take place, but accept that in a different context, they operate differently [11]. In Meng's case the Court engaged in the transfer of the foreign environmental context in which the alleged conduct took place, without transplanting the law itself. It did so to help interpret the local law, to identify the 'essence' of the offence. This raises different but related questions from those often asked in relation to legal transplants. For example, is law separable from its social context? Can social context be transplanted without also transplanting the law, or at least some background law to provide legal context? Can law,

\footnotetext{
${ }^{7}$ Watson, A. (1993). Legal Transplants: An Approach to Comparative Law, University of Georgia Press.

${ }^{8}$ Siems, M. (2014). "The curious case of overfitting legal transplants." The Method and Culture of Comparative Law: Essays in Honour of Mark Van Hoecke, Oxford: Hart Publishing: 133-146.

${ }^{9}$ Siems, M. (2018). "Malicious legal transplants." Legal Studies 38(1): 103-119.

${ }^{10}$ Legrand, P. (1997). "The impossibility of 'legal transplants'." Maastricht Journal of European and Comparative Law 4(2): 111-124.

${ }^{11}$ Whitman, J. Q. (2003). "The neo-Romantic turn." Comparative legal studies: Traditions and transitions 312.
} 
transplanted to help interpret conduct, be prevented from operating in the new context?

\section{2) EU Law Transposition}

In what can be seen as a continuing reception process, the mechanism by which European Union member states implement directives at the domestic level, usually through primary or secondary legislation, has built up its own terminology. The metaphor is that of transposition, the same as adopted in the extradition context of which Meng's case is part. A member state going beyond a directive's requirement is termed 'goldplating' while implementing a different scope, requirement or definition is 'diverging'. Where overlap is created between the directive and existing domestic laws, 'double-banking' is said to take place, and 'regulatory creep' describes overenthusiastic enforcement of the regulation.

Domestically created law may likewise address a particular mischief, fail to do so or work well but have additional unforeseen consequences; in all cases, its introduction into an existing legal environment causes everything to reshuffle to accommodate it. Accordingly, when new statutory law is introduced in common law jurisdictions, amending provisions simultaneously change other directly affected laws. This essential part of the process aims to avoid creating conflicts with existing law; where it doesn't, people must go to court for a decision, or wait for a new law to be passed.

\section{3) The Case of Meng Wanzhou}

\section{a. The Alleged Facts}

For the purposes of the application before the Canadian Court, the unproven allegations against Ms Meng must be taken as true or unchallenged. These are that Ms Meng misled HSBC, an international bank, concerning Huawei's relationship with a company operating in Iran named Skycom Tech. HSBC extended a financial facility to Huawei which it might not have done had those representations not been made and the true relationship with Skycom been disclosed. HSBC is said to have been put at risk of fines and penalties as well as a reputational risk because of United States' sanctions against Iran. In applying the double criminality test, the Court had to determine whether Ms Meng's conduct, had it taken place in Canada, would have amounted to a crime. Canada does not have equivalent sanctions against Iran and did not at the time Ms Meng is said to have made the representations in August 2013. The Parties therefore agreed that financial institutions in Canada engaging in financial transactions or providing credit to companies doing business in Iran would not have been at risk of penalty. The question for the Court was whether this precluded an offence being established in the circumstances of this case.

\section{a) The Law}

Relevant provisions of the Extradition Act, [ 12 ] paragraphs 3(1)(b) and 29(1)(a), provide:

3 (1) A person may be extradited from Canada in accordance with this Act and a relevant extradition agreement on the request of an extradition partner for the purpose of prosecuting the person .... if

...

(b) the conduct of the person, had it occurred in Canada, would have constituted an offence ....

29 (1) A judge shall order the committal of the person into custody to await surrender if

(a) in the case of a person sought for prosecution, there is evidence admissible under this Act of conduct that, had it occurred in Canada, would justify committal for trial in Canada on the offence set out in the authority to proceed $\cdots$

The alleged offence of fraud in Canada is found in section 380(1)(a) of the Criminal Code:[13]

380 (1) Everyone who, by deceit, falsehood or other fraudulent means, whether or not it is a false pretence within the meaning of this Act, defrauds the public or any person, whether ascertained or not, of any property, money or valuable security or any service,

(a) is guilty of an indictable offence and liable to a term of imprisonment not exceeding fourteen years, where the subject-matter of the offence is a testamentary instrument or the value of the subject-matter of the offence exceeds five thousand dollars ....

Under the Act, the alleged conduct, had it taken place in Canada, and must therefore have constituted an offence. The offence relied upon under the Code, fraud, has two limbs, dishonesty and what the Court termed 'corresponding deprivation.' Neither the Act nor the Code requirements refer to foreign law or context. For this, one must turn to the case law.

A central issue for the Court was the extent to which the US "sanctions" against Iran were relevant. Given the Parties' agreement that financial institutions in Canada engaging in financial transactions or providing credit to companies doing business in Iran

${ }^{12}$ S.C. 1999, c. 18
${ }^{13}$ R.S.C., 1985 , c. C-46. 
would not have been at risk of penalty, it would appear difficult to satisfy the second limb of the offence, guidance upon which was relied upon by the Court from McLachlin $\mathrm{J}$. in $R v$ Zlatic [14] who said the second limb required proof of 'deprivation caused by the prohibited act, which may consist in actual loss or the placing of the victim's pecuniary interests at risk.'

\section{4) The Court's Analysis}

\section{a) Proceeding without the Foreign Element}

The Attorney General's case for establishing this second limb of deprivation was put on two bases, the first not requiring consideration of the foreign context that is the link to sanctions. The Attorney General said the offence of fraud could be established without such reference, that risk was caused to HSBC 'entirely independent of US sanctions [15].

The Court had no difficulty in deciding that the Attorney General's first basis for establishing deprivation was insufficient. The misrepresentation must have been 'material or meaningful' in that it could 'give rise to loss or risk of loss to the deceived party.' This recognition of the causal link to the second limb of the offence is why deceit or a lie in and of itself does not amount to fraud [16].

The case against Ms Meng, in the Court's view, relied on the effect of the US Sanctions to establish the causal link between the misrepresentation and the risk of deprivation. The Attorney General's attempts to establish the potential for HSBC to have suffered loss unrelated to the US Sanctions failed, the Court holding:

Without reference to the US sanctions, the ROC and the SROC do not set out a causal basis (beyond the theoretical or speculative) for economic or reputational risk to HSBC because of Ms. Meng's alleged misrepresentations [17].

The Court is therefore clear that, without consideration of the US Sanctions, a matter of US law, double criminality is not satisfied because one of the essential limbs of the offence is not established. Taken together with the Parties' agreed position that financial institutions in Canada engaging in financial transactions or providing credit to companies doing business in Iran would not have been at risk of penalty, the only possible conclusion is that, adopting the wording of

${ }^{14}$ [1993] 2 S.C.R. 29 at 43. The case further breaks down the actus reus and mens rea of the offence, neither of which could be established according to Ms Meng's side, because there were no sanctions against Iran in Canada.

${ }^{15} \mathrm{~g}[37$

${ }^{16}$ I[40-42

${ }^{17} \mathrm{~g}[52$ paragraph 29(1)(a) of the Act, 'the conduct of the person, had it occurred in Canada' could not have constituted an offence.

The Court proceeded to consider the foreign context based on the Attorney General's second basis for establishing deprivation. Transplantation of the foreign social context is introduced through case authorities [18] which speak about transposing the relevant conduct fact pattern to be assessed according to Canadian law.

\section{5) Introducing the Foreign Element}

Two exercises are identified as inappropriate by the Court. First, the extradition judge should not assess whether the offence can be made out in the foreign state. Secondly, there is no need to review the foreign law to see whether the two laws match [19]. I turn to the process by which the Court determined that the foreign environment could be introduced and used in the case, including what might be termed 'background laws', that is those which impact on the accused in the foreign context but not the equivalent law giving rise to the alleged offence.

The Court was concerned with the 'essence' or 'essential nature' of the alleged conduct at a certain 'level of abstraction [20]. The Court considered that 'for an offence such as fraud', apparently singling out fraud for differential treatment, the 'conduct' being considered 'as though it took place in Canada' must 'have a more general scope' [21] than that proposed by Ms Meng. The position put forward by Ms Meng was simply that each fact must be transposed as if it took place on Canadian soil in an entirely Canadian context [22].

Although the Court here suggests some offences should be subject to different considerations, without providing the basis for such proposition, the justification for turning to foreign context considerations is to 'have a more general scope' than 'Canadian soil' and 'an entirely Canadian context' might offer. The sense of 'more general' in this application can only point to non-Canadian soil and a non-Canadian context, which would appear to go beyond the wording of the Act which limits the test to consideration of 'the conduct of the person, had it occurred in Canada'[23]. How far beyond the border should we venture?

\footnotetext{
${ }^{18}$ United States of America v. McVey, [1992] 3 S.C.R. 475, Fischbacher, and M.M. v. United States of America.

${ }^{19} \mathrm{I} 56$

${ }^{20} \mathrm{TI} 58$

${ }^{21} \mathrm{I} 60$

22 II59

${ }^{23}$ S.C. 1999 , c. $18, \llbracket 3(1)(b)$
} 
The Court's concern was that by unduly isolating the 'specific facts said to comprise the overall fraud', one lost sight of the 'overall effect' and 'essence' of the alleged conduct [24]. However, as $R v$ Zlatic establishes, the offence of fraud comprises specific elements, not an 'overall effect' or 'essence'. A conviction cannot be secured on the basis of the latter. There is, further, no offence of 'overall fraud' or any definition indicating where to draw parameters. Is this an attempt to redefine the offence or linguistic confusion arising out of frustration that the law will not fit?

The Court is seeking to recontextualise the law, which must necessarily change the law, but claiming only to add context to the conduct. Put another way, the Court is striving for a normative assessment of the conduct because of a perception that a positive assessment does not tell the full story. However, in doing this, the law is put under strain, being made to shift; the act of fraud is singled out for different treatment from other offences, and a concept of 'overall fraud' is posited to make way for the introduction (into what must otherwise be a closed system of review - the double criminality test) of the foreign element of transplanted context. The opacity of 'overall' as a delimiting qualifier leaves the boundaries of fraud unrestrained.

The forced introduction of the foreign context in linguistic terms of 'essence', 'essential nature', 'overall' and 'general' contrasts with the Court's language used to describe Ms Meng's position: 'very concrete and specific', 'unduly isolates', 'entirely Canadian context'. The rigid legal analysis is made to give way to the generality of the foreign setting.

Straining further, in circumstances where the Parties agreed there was no authority establishing whether the 'essence' of conduct said to amount to fraud could include the legal context in which the alleged statements were made, the Court decided it could. It did so based on a case involving perjury where double criminality was not considered, [25] and by stating a hypothetical scenario in which it concluded the exercise could take place [26]. The jurisgenerative conclusion following hard upon the terminological struggle belie the Court's projection of a natural exercise. The reaching out to normative contextualism appears strained, in part because the problem it is introduced to solve (aiding the interpretation of 'overall fraud') exists only because the Court has created it. One risk is creating the impression not of applying law to the facts to achieve a result, but rather the exercise in reverse.

\footnotetext{
${ }^{24}$ II60

25 United States of America v. Wilson, 2013 BCSC 2423, aff'd 2016 BCCA 326

${ }^{26} \$ 61$
}

This sense of imbalance is heightened by the Court's mini polemic on the iniquity of fraud, [27] again suggesting it should be considered apart from other offences, and the Court's opinion that although the US Sanctions are not part of Canadian Law, 'they are also not fundamentally contrary to Canadian values in the way that slavery laws would be.'[28]. This suggestion that we can let the good laws in while keeping the bad ones out again has no basis in law. It introduces discretion absent in the Extradition Act, the Criminal Code as well as precedent.

\section{6) Effect of the Foreign Element}

Once the foreign context is introduced, it is instructive to observe its effect and how it is allowed to operate. The Court in Meng's case considered two cases where the foreign law context has been considered by courts faced with parties resisting extradition. In the first, a defendant accused of perjury said the person administering the oath would not have been qualified to do so in the extraditing country, so no offence would have been committed [29]. In the second, it was claimed that the different definitions of 'income' in the requesting and extraditing countries would likewise have precluded an offence related to tax fraud [30].

Both cases considered the role of the environment in which the conduct took place. In $R e$ Collins, Duff J held:

...if you are to conceive the accused pursuing the conduct in question in this country, then along with him you are to transplant his environment; that environment must, I apprehend, include, so far as relevant, the local institutions of the demanding country, the laws affecting the legal powers and rights, and fixing the legal character of the acts of the persons concerned.

... you have an oath taken in a judicial proceeding before a court of competent jurisdiction after a manner in which it was authorized by law. These facts make up the substance and essence of the "criminality" charged against the accused.

What is happening in these cases is not just the context transfer. Specifically, care is taken so that the foreign law is not being transplanted, in either direction

\footnotetext{
${ }^{27} \mathrm{~d}[82$

${ }^{28} \mathrm{~d} 8 \mathrm{85}$

${ }^{29}$ Re Collins (No. 3) (1905), 10 C.C.C. 80 (B.C.S.C.)

${ }^{30}$ Germany (Federal Republic) v. Schreiber, (2004), 184 C.C.C. (3d) 367 (Ont. S.C.), and (2006), 206 C.C.C. (3d) 339 (Ont. C.A.)
} 
[31]. In both cases, had the foreign law been allowed to operate, it would have led to the opposite result - no proper oath would have been taken and so no offence of perjury committed [32] and the definition of income would mean there was no tax fraud. In both cases, the law is taken into account in the contextual analysis, but it stays where it is, not moving to take part in the determining jurisdiction. It is a passive aspect of the foreign legal landscape, not performative.

By contrast, in Ms Meng's case, the US sanctions provisions, bundled along with other 'conduct context' are transposed not just to play a part in the overall contextual analysis (the legal landscape) but critically to satisfy an otherwise absent element of the alleged offence, without which, as the Court accepts, the double criminality test could not be satisfied [33].

The Court further fails to observe the transplanted law from the background to the foreground by determining that 'The US sanctions are part of the state of affairs necessary to explain how HSBC was at risk, but they are not themselves an intrinsic part of the conduct.' [34]. The Court's blind spot here hides the fact that the second limb of fraud, the 'corresponding deprivation' [35] is seldom 'an intrinsic part of the conduct' but more usually a consequence outside the control of the offender. Deception is satisfied through conduct but deprivation, an essential element of the offence may not. In Canada, financial institutions are not subject to prosecution if they do business with Iranian entities, so there would be no detriment. In the United States of America, the opposite is true. In neither case is this down to the accused's conduct, but rather the legal environment or context. The Court in Ms Meng's case claims only to have transposed 'part of the state of affairs necessary to explain how HSBC was at risk', but it is precisely this that has changed a misrepresentation with no corresponding deprivation into the offence of fraud.

\footnotetext{
${ }^{31}$ In Meng's case, the Court highlighted part of Duff J's ruling. The part which was not highlighted includes the critical qualification of the law that can be transplanted 'always excepting, of course, the law supplying the definition of the crime which is charged.'

${ }^{32}$ The defence was effectively claiming no offence would have been committed in the foreign territory if local law requirements were applied, because the oath administrator would not have been authorised.

${ }^{33}$ In Meng's case, this is precisely the point made by Ms Meng's legal team, that the legal context in Collins and Schrieber related to matters which did not comprise core elements of the offence, whereas in the present case, the foreign law relates to a core element of the offence and so should not be transposed to the domestic aspect of the double criminality analysis. II77 The Court however did not agree.

${ }^{34}$ II 80

${ }^{35} \mathrm{I}[25$
}

The initial mischaracterisation has allowed the US Sanctions to be introduced as a passive aspect of the legal landscape or context and then repurposed to satisfy a core element of the offence. There is nothing supportive of this usage in the sources of law upon which the Court relied.

\section{CONCLUSION}

This analysis of the Court's decision in Meng's case highlights the complexity and codependency between law and its social context, its shifting nature and the artificiality of the attempted isolation of either. The use of foreign context in both $R e$ Collins and Schreiber was, I suggest, balanced by ensuring that the law was not permitted any performative role in the new context and was rather limited to that of background. The double criminality safeguard was thereby preserved.

However, once the foreign law is permitted an active role in the domestic context, there is no longer a double test but a mixed or blended one, open to the risk that criminality in one regime would always suffice, or perversely that conduct not amounting to an offence in either, might satisfy the test when laws from the two systems are combined. In Meng's case, foreign law has breached the double criminality barrier and served to satisfy an otherwise absent element of the domestic offence. Whether the Court is conscious of this, its apparent transgression from the prescribed test affects not just Ms Meng's case but provides a potentially unanticipated precedent for the differential treatment of offences under the Extradition Act and an erosion of the double criminality test whereby foreign law may take a performative role in establishing domestic criminality that is otherwise absent.

Sean D. Yates 